\title{
Status of the Young People from the Indigenous National Minority Groups - as a Phenomenon and Its Exemplification in the Visegrad Group Countries Within the Integration Processes with the European Union
}

\author{
"Status" is a relative position of an individual \\ and thus it depends on the fact who the others are
}

(Sowa, 1962, p. 59)

\begin{abstract}
The present article tackles the topic of the status of young people in the multicultural environment. The status of the young people from the indigenous minority determined by them is compared with the evaluation of the minority status by the young people from the majority living in the same environment. This topic is considered relevant for the quality of "intercultural milieu” and the identity of the society living in the particular environment.

The objective of the article is to show the changes of the minority status by comparing the opinions in that matter recorded in the years before joining the EU and those expressed in 2010. We consider consequences of the changes in "intercultural approaches" in the particular environment within the integration processes in the EU.

The way of presenting the topic is based on the theory of „groups of mutual reference". The results of the study presented in the article refer to the dimensions of valued resources and opportunities, and in particular opinions of young people considering their availability for the minority, which illustrates the position of group members and their status and prestige.

Further, there is a comparison of opinions of young people from minority and majority groups concerning access to resources and opportunities for the indigenous minority group. This shows positioning of the minority, and at the same time
\end{abstract}

Faculty of Ethnology and Educational Science in Cieszyn, University of Silesia in Katowice, Poland, E-MAIL: urban.a@volny.cz. 
establishes the position of majority in the particular environment. The opinions comprise a lot of information about relationships and ways of communication in the society, that is "interculturalism": "«Status» is a relative position of an individual and thus it depends on the fact who the others are" (Sowa, 1962, p. 59).

\section{Keywords:}

minority status, „interculturalism”, national minority.

\section{INTRODUCTION: "INTERCULTURALISM" OF THE ENVIRONMENT}

Intercultural environment forms a number of various kinds of reality. The space assigned to the minority and accepted by the minority group as well as relations characteristic for the society determine the nature of created "interculturalism"2, at the same time defining identity of both minority and majority groups. Yet, relations creating the reality refer to its various dimensions. Marian Kempny (1997) points out that "categories that accompany interculturalism do not constitute only its intellectual dimension, but refer to the inalienable rights of the individual and societies, that is, the area of politics and ideology" (pp. 278-279). In the first place, it is valid about the environment with an indigenous national minority where inclusion and exclusion in various forms are particularly conspicuous. John Rex (1996) distinguishes three possible forms of "accepting” a minority group: assimilation process of the minority group as regular citizens based on the same rules; subordination of the minority group; recognition of cultural diversity in a private sphere and maintaining the common political culture in public. It is significant that the way of accepting minority depends not only on their identity but it depends to the same extent on the majority identity. "The new national identity of the host society will depend upon the outcome of processes which follow from the adoption of these different policies” (Rex, 1996, p. 1).

Consideration of various concepts related to liaison of minority-majority requires to be aware of a number of dimensions that involve determining the minority group position within the intercultural environment, as well as determining ways of communication. Tadeusz Paleczny (2009, p. 18) points out that "intercultural dialogue" is not an ordinary way of communication but it involves social, political and economic phenomena, both within and without cultures. The situation of the individual determines his/her status. When acknowledging the

2 I owe the terms to M. Rey (1996, as referred in: Grzybowski, 2007, p. 260) who - in accordance with the interpretation the Council of Europe applies (Grzybowski, 2007) - defined "multiculturalism" as a concept applied to describe a particular environment, the concept of "intercultural” to describe social processes taking place there. 
intercultural approach and equality of subjects communicating (Olbrycht, 2003, p. 213), then the status should be determined without taking into account the minority-majority division.

The present article tackles the topic of the status of young people in the multicultural environment and makes a comparison of the status as evaluated by the minority and majority groups. The status of the young people from the indigenous minority determined by them is compared with the assessment of the minority status by the young people from the majority living in the same environment. This topic is considered relevant for the quality of "intercultural milieu" and the identity of the society living in the particular environment.

The objective of the article is to show the changes of the minority status by comparing the opinions in that matter recorded in the years before joining the EU and those expressed in 2010. We consider consequences of the changes in "intercultural approaches" in the particular environment within the integration processes in the $\mathrm{EU}^{3}$. The social position of the minority determines its social capital, which in turn is modified both by minority and majority opinions. Young people's opinions belong both to minority and majority groups and refer to availability of valued resources in society to the minority group. The opinions show the minority position in the society and simultaneously they illustrate the majority position. Statements make inclusion as well as exclusion conspicuous and changes of the minority position in the young people's views prove what changed in their attitudes towards the "intercultural approach" in the particular environment.

The attitude towards assimilation seems to be essential to be studied both in the minority and majority groups. Hieronim Kubiak (1980, p. 23) points out that it is necessary to carry out theoretical studies of assimilation ideologies and their structure and functions - and we can add: multicultural ones as well. They seem to be a significant factor influencing assimilation processes (p. 23) - and we add: shaping the character of "intercultural attitudes" as well.

3 Discussion in this article tackles the changes of young people's status in the particular environment of the indigenous minorities in the Visegrad Group countries (the particular environment is specified in the text of the legend to the table) in the integration processes with the EU and compares years 2004 and 2010. The author's own research from 2010 (January - May) is discussed and compared with the results in 2004 (January - April). Research in 2010 was carried out in the same schools and among the similarly chosen high school graduates (altogether 985 respondents, specified in the legend to the table) like the research in 2004, which was analyzed and discussed in the dissertation (Urban, 2014). There is a wide theoretical and methodological material (partly referred to in this article) as well as the system of selection of the respondents (altogether 703 respondents). The scope of the themes of research required the conscious evaluation of the fact of joining the EU, and reflection of the young people on their possibilities and access to resources in the new situation (more in: Urban, 2014). 


\section{MINORITY STATUS IN THE YOUNG PEOPLE'S OPINIONS FROM THE INDIGENOUS MINORITY ENVIRONMENT}

\section{STATUS - A FEW REMARKS INTRODUCING THE TOPIC}

Piotr Sztompka (1989) - defining the structure as a hidden "net of permanent and regular links between the elements of a part of reality which has a decisive impact on the progress of observable phenomena in that area” (pp. 52-53) - distinguishes four dimensions of the structure (pp. 54-55). They are the following dimensions: normative, ideal, interactive of the structure (deep and determining organizational systems of groups, determining ways of facilitation in the environment); valued resources and opportunities: "access to affluence, power, prestige, knowledge, etc.” (p. 55). Prestige scales show social stratification and thus it is a standard tool to measure occupational aspirations. In sociology, "a prestige scale is perceived by people as the reflection of the social stratification system” (Domański, 2004, p. 200). William L. Warner was the first to apply prestige scales to determine social stratification. When defining other dimensions of stratification he considered them to be "subordinate and worth studying only gathering opinions of the individuals who designate status of other members of the society" (Szacki, 2003, p. 625).

In the multicultural environment, particularly with an indigenous minority, when minority and majority function as the groups of mutual reference4: "Diagnosis of one's own situation takes place [...] in the process of complementary diagnosis of someone else's situation” (Miluska, 1995, p. 39). Mutual opinions about each other are significant in the society - "structures of close distance" allow to perceive hierarchy - positions, status and social roles, that is, the simple and primal elements of social structures (Szmatka, 2008, pp. 127, 129). Comparison of positioning of status determines self-appraisal of individuals and groups. “«Status» is a relative position of an individual and thus it depends on the fact who the others are" (Sowa, 1962, p. 59). The picture of the situation is most conspicuous on the immediate level of the society where mezo- and macro- hierarchy levels of reality get reflected. To sum up, the issue of minority status in the multicultural environment on the border is the issue of their position, prestige and, in consequence, of the kind of "interculturality" of the particular environment.

The results of the study presented in the article refer to the dimensions of valued resources and opportunities, and in particular to opinions of young peo-

4 Minority-majority groups creating the common environment discussed in the article compare also the dissertation (Urban 2014) - fulfil the criteria of the "groups of mutual reference" (Merton, 1982; Sowa, 1962). On various ways of tackling "groups of reference”, see Skeris (2004). See also: Skeris (1979), Posern-Zielińska (1975). 
ple considering their availability for the minority, which illustrates the position of group members and their status and prestige. The attained level of education belongs to the basic resources of an individual and determines the course of one's career, social prestige, self-appraisal, values and their availability (Domański, 2002, p. 89). The aim of the study is to show changes in the status of young people in the environment with an indigenous minority in the Visegrad Group countries. Compared opinions expressed by young people in the years 2004 and 2010, respectively, are discussed here. Further, here is a comparison of opinions of young people from minority and majority groups concerning access to resources and opportunities for the indigenous minority group. This shows positioning of the minority, at the same time establishing the position of majority in the particular environment. The opinions comprise a lot of information about relationships and ways of communication in the society.

\section{EXEMPLIFICATION OF THE CHANGES OF MINORITY STATUS IN THE PROCESS OF INTEGRATION WITH THE EU}

The issue concerning the social capital of the representatives of national minority is equivalent to the issue concerning prestige, availability of valued resources and positioning in the system of social stratification. "High quality education" and "well-paid job" are mentioned as the most important resources and the status is determined by their availability.

National minorities are considered to be a social category affected or endangered by exclusion. The research distinguishes two ways of defining this concept, relational and distributional (Jasińska-Kania \& Łodziński, 2009, p. 9). The latter one is being used when the lack of availability or limited access to important resources is emphasized. Markers of prestige position and of social stratification are different in studies written by different authors. They are established in comparison with "other groups with reference to access to important resources such as education and employment” (Jasińska-Kania \& Łodziński, 2009, pp. 12-13). The issues of "high quality education" and "a well-paid job” seem to be the most important ones for young people.

Studying opinions concerning access to valued resources for young people, such as "high quality education" and "well-paid job" as well as availability of affluence, political power, prestigious occupations, is based on the premise that availability of all the mentioned above is conditioned by membership of majority-minority groups. "Stratification means differentiation of the society as a whole in terms of income, education, social position and prestige. Social stratification means differences in classes and social stratification layers within each class [...] 
that entails access to power, privileges and jobs” (Dyoniziak, Iwanicka, Karwińska, Nikołajew, \& Pucek, 1999, p. 16).

In all the groups, both minority groups $(\mathrm{M})$ and majority groups $(\mathrm{Mj})$, only $8-26 \%$ high school graduates taking part in research in $2004^{5}$ think that minority groups have restricted access to wealth, quality education and well-paid jobs. Only in Hungary a significant number of young people estimate that minority groups have restricted access to wealth (M/Mj: 60\%/42\%), quality education ( $\mathrm{M} / \mathrm{Mj}$ : 60\%/42\%), and well-paid jobs (M/Mj: 41\%/32\%).

The picture changed definitely when it comes to political power and prestigious positions.

In 2004, access to prestigious positions for minorities scores high for both groups in Czechia and for the majority in Slovakia ("limited access": 9\%-26\%), whereas both groups in Poland and the minority group in Slovakia scored lower ("limited access": 32\%-40\%), Hungary scored much lower ("limited access" - minority and majority respectively: 52\% and 61\%). Access to political power is still more restricted for the minorities in opinions of high school graduates. In Poland, minority and majority groups scored respectively $61 \%$ and 49,5\%, Hungarian majority scored $63 \%$ and all the groups in Czechia and Slovakia and the minority group in Hungary scored 35\%-43\%.

Analysis focuses on comparison of scores in 2004 with the matching scores in 2010. Taking into account changes within particular categories, indications and attempts to generalise are presented (see Table 1), opinions of the selected groups in the particular years or majority and minority groups in the same environment and at the same time. People and their attitudes in the particular groups are sensitive to certain local incidents. Thus it is not possible to interpret all the results due to political changes taking place in the countries which had certain impact on the change of attitudes. So it is necessary to indicate that this kind of aspect occurs.

In 2010, similarly to 2004, both groups in Czechia and the majority group in Poland scored high on the access to "prestigious positions" (lack of equal access - was declared by 16\%-33\% high school graduates, in 2010 there was a difference by $5 \%-10 \%$ students). In 2010 , other groups thought the access to be more difficult ("limited access" scored by $40 \%-50 \%$ ). To be more precise, the minority group in Poland did not change the scores ("limited access" about 40\%). The higher scores were in Slovakia - the minority group showed an increase by 10\% (in 2010:

$5 \quad$ All the data - author's own research - see Table 1, data concerning 2004 were part of the dissertation (Urban, 2014). The span of numbers (e.g., 8-26\%) means that for the particular group the graduates' answers quoted in \% maybe found within the span. We continue to use the following abbreviations: M stands for Minority; Mj stands for Majority. 
Table 1. Opinions referring to the lack of equal availability of valued resources for the minority

\begin{tabular}{|c|c|c|c|c|c|c|c|c|c|c|c|c|c|c|c|c|}
\hline & \multicolumn{4}{|c|}{ Poland } & \multicolumn{4}{|c|}{ Czech Republic } & \multicolumn{4}{|c|}{ Slovakia } & \multicolumn{4}{|c|}{ Hungary } \\
\hline & \multicolumn{2}{|c|}{$\mathrm{M}$} & \multicolumn{2}{|c|}{$\mathrm{Mj}$} & \multicolumn{2}{|c|}{$\mathrm{M}$} & \multicolumn{2}{|c|}{$\mathrm{Mj}$} & \multicolumn{2}{|c|}{$\mathrm{M}$} & \multicolumn{2}{|c|}{$\mathrm{Mj}$} & \multicolumn{2}{|c|}{$\mathrm{M}$} & \multicolumn{2}{|c|}{$\mathrm{Mj}$} \\
\hline & $\begin{array}{l}2004 \\
(30)^{*}\end{array}$ & $\begin{array}{c}2010 \\
(48)\end{array}$ & $\begin{array}{c}2004 \\
(131)\end{array}$ & $\begin{array}{l}2010 \\
(183)\end{array}$ & $\begin{array}{c}\mathbf{2 0 0 4} \\
(105)\end{array}$ & $\begin{array}{l}2010 \\
(102)\end{array}$ & $\begin{array}{c}\mathbf{2 0 0 4} \\
(79)\end{array}$ & $\begin{array}{c}2010 \\
(83)\end{array}$ & $\begin{array}{c}2004 \\
(80)\end{array}$ & $\begin{array}{c}2010 \\
(113)\end{array}$ & $\begin{array}{c}2004 \\
(159)\end{array}$ & $\begin{array}{l}2010 \\
(269)\end{array}$ & $\begin{array}{c}2004 \\
(24)\end{array}$ & $\begin{array}{c}2010 \\
(31)\end{array}$ & $\begin{array}{c}\mathbf{2 0 0 4} \\
(95)\end{array}$ & $\begin{array}{l}2010 \\
(156)\end{array}$ \\
\hline Wealth & 14,9 & 33,3 & 14,9 & 18,4 & 8,5 & 8,5 & 22,9 & 30,2 & 16,9 & 61,4 & 11,9 & 63,2 & 59,8 & 27,8 & 41,7 & 25,0 \\
\hline Political authority & 61,0 & 47,9 & 49,5 & 37,1 & 37,8 & 28,1 & 40,9 & 41,5 & 37,7 & 38,5 & 36,5 & 43,5 & 37,6 & 77,8 & 63,6 & 58,2 \\
\hline Prestigious positions & 40,2 & 41,7 & 32,9 & 22,9 & 10 & 15,7 & 26,5 & 30,2 & 38.2 & 46,8 & 23,1 & 50,3 & 51,9 & 44,4 & 61,3 & 47,3 \\
\hline High quality education & 15,1 & 16,6 & 14,8 & 15,8 & 7,9 & 9,4 & 21,8 & 28,3 & 21,9 & 65,7 & 20,9 & 61,9 & 59,9 & 16,7 & 41,6 & 27,6 \\
\hline Well-paid jobs & 11,9 & 22,9 & 25,8 & 15,1 & 8,4 & 15,6 & 26,2 & 39,6 & 21,8 & 62,4 & 21,3 & 60,3 & 40,9 & 33,3 & 32,8 & 36,2 \\
\hline Assimilation & 50,0 & 16,6 & 47,4 & 42,6 & 25,6 & 28,1 & 54,4 & 35,8 & 50,0 & 32,5 & 46,4 & 40,7 & 16,4 & 22,2 & 61,3 & 40,7 \\
\hline
\end{tabular}

Legend: Answers to questions Do you think that national minorities: a/ have limited access to the values such as...?; b/ should assimilate? (for the line: "assimilation"). In the table in columns there are: $1 /{ }^{*}$ number of respondents (in brackets); 2 / numeric entries (in \%) gathered in years 2004 and 2010 (in bold) respectively for minority and majority groups with the indigenous minority group: German minority in Poland, Polish minority in the Czech Republic (in the text also Czechia), Hungarian minority in Slovakia, Slovak minority in Hungary. The chart of the responses "Yes" (given in \%) - the answer means "yes, minorities have limited access to...": "wealth", "political power", "prestigious positions", "quality education", "well-paid jobs"... "assimilation"; used in the table and used further there are abbreviations in the text: M for Minority, Mj for Majority. 
$M-47 \%)$, the majority group showed an increase by 25\% (2010: $\mathrm{Mj}-50 \%)$. In Hungary, the scores for the lack of equal access lowered: by 5\% in the minority group (2010: 45\%), by 14\% in the majority group (2010: 47\%).

In 2010, the scores on the vision of equal availability of political power rose for both groups in Poland by more than 10\% ("limited" access in 2010: M - 48\%; Mj - 37\%), moderately in the majority group in Hungary (by 5\% - "limited" access in 2010 - 58\%), for the minority the score fell down dramatically by $40 \%$ (which means in 2004 - 38\%; in 2010 - 78\%). Groups in Czechia and Slovakia scored similarly and nearly without any changes ("limited" access: $36 \%-44 \%$, only the minority in Czechia - 28\%).

In 2010, apart from both groups in Hungary, the scores on the vision of access to wealth by minority groups decreased. The high school graduates from all the groups in Poland and Czechia evaluated highly the access to wealth ("limited" access: 9\%-33\%). For the minority group in Poland and majority group in Czechia there was respectively nearly 20 and 10 per cent rise on the criterion referring to the lack of access to wealth by the minority, which in 2010 meant the following score: PL $-33 \%$; $C Z-30 \%$. Slovak minority and majority groups found the access to wealth more difficult. Comparing 2010 with 2004, the score rose by $45 \%$ and $51 \%$, respectively. For Hungarian groups the number of opinions referring to the lack of access to wealth lowered by $30 \%$ and 15\% (i.e., in 2010: $\mathrm{M}-28 \%$; $\mathrm{Mj}$ $-25 \%)$.

This article focuses on the opinions referring to access to "valued resources" that are the most important for the young people. Namely, they are "high quality education" and "well-paid jobs". Another objective is to show how the opinions were changing between 2004 and 2010. As it has been mentioned above (Domański, 2002, p. 89), high quality education belongs to the basic resources that may determine careers. The obtained academic degree determines one's prestige, self-appraisal, values and opens opportunities to access other resources. Aspirations of young people concerning education are worth studying with serious consideration. In 2004, expectations pertaining to university education (Urban, 2014) were very high (93-100\%), and students in Hungary were the only exception (Mj - 77\%; M - 53\%). Let us look at high school graduates in 2010 who were aware of what kind of education to aim at. In all the groups in Poland, Czechia and Hungary, a high number of students declared to be willing to study at the university (92\%-96\%). Slovakia was different with lower scores on that issue ( $\mathrm{M}-85 \%$; $\mathrm{Mj}-89 \%)$. All groups had a number of respondents who were not certain what to do ("I do not know", or no answer). Percentage of the answers of that kind was similar for minority and majority groups from the same environment. However, 
it was different in different countries, in particular both groups in Czechia made $3 \%$, Hungary $-5 \%$, Slovakia $12 \%$ for (M) and $15 \%$ for $(\mathrm{Mj})$, whereas in Poland it was quite high: $39 \%$ for $(\mathrm{M})$ and $37 \%$ for $(\mathrm{Mj})$.

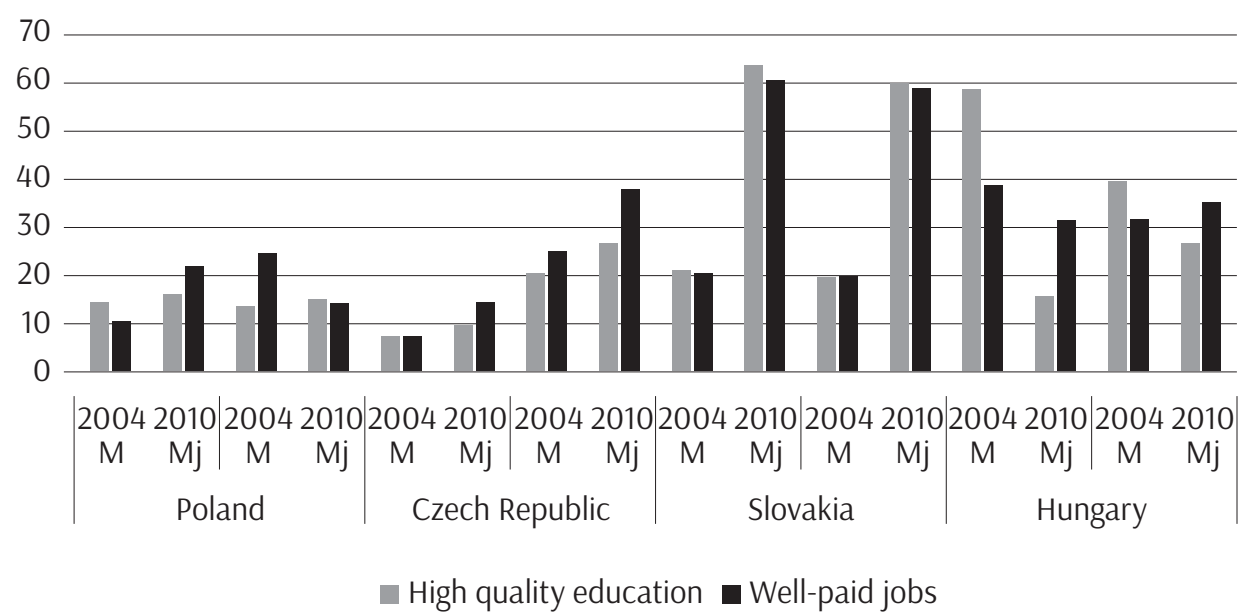

Chart 1. Lack of equal access to "high quality education" and "well-paid jobs" for minorities - high school graduates' opinions from minority and majority schools in the multicultural environment of the Visegrad Group countries in 2004 and 2010

Legend: Do you think that minorities have limited access to "high quality education" and "wellpaid jobs"? A chart showing the response "yes" (responses "yes, they have limited access" are given in \%, numeric response is in Table 1). See the legend to Table 1.

An attempt to summarize the answers concerning opinions on access to "high quality education" and "well-paid jobs" shows ("limited" access - minorities: Table 1; pictorial image - Chart 1) that lack of access is pointed out by a higher number of high school graduates in 2010 than in 2004.

The score on lack of access to "high quality education" for minorities was similar in 2004 and 2010 in every group in Poland (M and Mj about 15\%) and Czechia ( $\mathrm{M}$ about $8 \%$ and $\mathrm{Mj}$ about 25\%). At the same time among all the mentioned above resources the score on access was the highest in those groups. The score on lack of access to "well-paid jobs" differed by $10 \%$. In Poland in 2010, the scores on lack of access to "well-paid jobs" for minority increased to $22 \%$, for majority the scores lowered to 15\%. In Czechia, both groups scores fell in 2010 (lack of access in 2010: $\mathrm{M}-16 \%$; $\mathrm{Mj}-40 \%)$. In Slovakia, opinions on "high quality education" and "well-paid jobs" were nearly the same (M and Mj about 20\% in 2004) and in 2010 changed in the same way. In 2010, nearly the same number (about 60\%) of 
high school graduates in both groups expressed their opinions, which is about $40 \%$ when compared with 2004. In 2004, the minority in Hungary was very critical in evaluating their opportunities to access valued resources. Unlike in 2004, six years later when compared with the opinions of the majority, a number of members of the minority group claimed to have equal access to "high quality education"; that is $43 \%$ high school graduates more in the minority group whereas only $14 \%$ in the majority group. This makes 17\% (M) and 28\% (Mj). Scores for "well-paid job" differ by approximately 5\% (for 2010 - 33\% (M) and 36\% (Mj)).

To sum up opinions on access to other valued resources, it can be pointed out that:

- $\quad$ as far as wealth is considered, the scores rose in Hungary (M/Mj rose by $30 \% / 15 \%$ respectively), the scores are comparable elsewhere apart from Slovakia, where the scores decreased (M/Mj fell by 45\%/50\%);

- $\quad$ as far as political power is considered, the scores slightly rose in Poland, but they definitely decreased for the minority group in Hungary, the scores seem to be comparable for both groups in Czechia and in Slovakia, the same applies to the majority group in Hungary;

- $\quad$ as far as prestigious positions are considered, the situations are comparable both in Poland and Czechia, in Slovakia the scores decreased, however in Hungary the scores rose.

A pivotal factor for the minority vision is accepting the minority existence. This, in turn, allows to consider access to valued resources. In case of the minority group, the level of acceptance for assimilation of one's own group in Czechia did not change much, only about $28 \%$ high school graduates accept it. The scores rose in Hungary (by 6\%, i.e., in 2010 - 22\%), in Slovakia scores fell almost by 17\% (2010: 33\%), and in Poland scores fell by 33\% (2010: 17\%). The fact that the majority expects the minority group to assimilate is much more widespread when compared to expectations of the minority. In 2010, the scores decreased; and yet the level was still high: - in Poland and in Slovakia the scores were the same as in 2004, and what is more, for both majority and minority groups the scores were the same (about 40\%); - in Czechia and in Hungary the scores fell by about 20\%, which meant 36\% in Czechia and 41\% in Hungary.

When comparing approval of access to valued resources for the minority in 2004 (Urban, 2014) - only a few majority group respondents refused to recognize it - and the scores for their own prospects expectations, we find them similar. It is possible to conclude that there exists neither exclusion nor privileges. At the same time there exists disapproval to let the minority be visible and prominent in the particular society (Urban, 2014, pp. 386-391) - disapproval to let the minor- 
ity become conspicuous in public (use of both languages in public and bilingual notices). When comparing opinions referring to opportunities, we find incoherence, even a contradiction. The results above point out to the fact that the direct contact may infringe the emotional convictions, though it most probably develops cognitive dissonance.

\section{CONCLUSION - SOCIAL CAPITAL OF THE MINORITY WITHIN THE PARTICULAR MULTICULTURAL ENVIRONMENTS}

The issue of minority status is the issue of the place in social stratification which gives evidence about the extent of social capital which the individual disposes of (Szacki, 2003, p. 8986'). Determining one's own opportunities constitutes the social capital of the young people. "Social capital is a set of real and potential resources that are linked with [...] being a member of a group that provides support to every member such as the resources owned by the group, credibility that allows access to credit in its widest sense" (Sierocińska, 2011, p. 727). In the multicultural environment, in the time of social changes, the quality of social capital becomes all the more important. Social capital may become a phenomenon one feels deprived of or feels privileged to have access to.

The objective of the discussion was to show intercultural changes in the indigenous environment. This was done by studying opinions of high school graduates which allowed to indicate changes of minority positioning. The way of presenting the topic is based on the theory of "groups of mutual reference". "What determines the choice of certain reference indicators as important and established ones [...] as well as perceiving reference indicators as 'privilege' - these are the main theoretical issues” (Sowa, 1962, p. 59). Examining opinions from the perspective of accessibility of valued resources for minorities, particularly focusing on accessibility of "high quality education" and "well-paid jobs", the issues that concern students most, it is possible to claim that minority groups in 2004 did not feel deprived because of being a minority and the majority groups perceived the minority in the same way. The only exception was the Slovak minority in Hungary. It is feasible to claim that apart from the minority in Hungary, minority opinions indicate that they evaluate their opportunities without having the feeling of low self-esteem or

$6 \quad$ Author refers to: D. Swartz, Culture and Power. The Sociology of Pierre Bourdieu, Chicago 1997, pp. 154-157.

P. Bourdieu, The Forms of Capital. In: J. Richardson (Ed.), Handbook of Theory and Research for the Sociology of Education. New York 1986 (quoted in: Sierocińska, 2011, p. 72). 
feeling inferior towards the majority group (more in: Urban, 2014). However, since joining the EU, all the groups show significant changes in their attitudes towards minority groups. "Significant indicators of beliefs concerning social equality in various communities may constitute characteristics that determine the basic social equality. Those characteristics justify comparing and drawing conclusions" (Sowa, 1962, p. 58).

The most important issue for young people - accessibility of "high quality education" and “well-paid job” - did not change basically both in Poland and Czechia, whereas in Hungary accessibility got higher scores. However in Slovakia scores soared dramatically; in both categories by about 40\%; in 2004, the score was $20 \%$, in 2010 , the score rose to $60 \%$. The environment of that kind creates the feeling of the privileged majority. In the situation where a majority has a negative attitude and even it is negative towards their own minority, then taking advantage from the existing multicultural environment is scarce. What is more, the minority does not make use of biculturalism.

The feeling of deprivation makes the minority accept the stance that allows them to feel prone to assimilation. Assimilation processes are triggered by any discrepancy that arises from a conflict situation in the borderland, although the most important one is the natural consequence of living in the same environment, i.e., mixed marriages. The fact that there is a consent to assimilation by the potentially involved individuals makes the assimilation more likely. The fact of not accepting it - acknowledgement or improper acknowledgement (Taylor, 1995, p. 13) in the environment - makes it unavoidable. Mere expectations that the minority would eventually assimilate means that the minority is on the disadvantageous position (Witkowski, 1995, p. 16). Multiculturalism, as an active policy that supports recognition and permanent establishing of the notion "we", is the only one that may prevent denationalization and assimilation. When accomplishing this kind of task, it is necessary to point out the significance of intercultural education. We find there important principles of content analysis, namely "knowledge and relationship towards Others", as well as "self-perception and perception of one's own identity in the multicultural world" (Lewowicki, 2011, p. 34).

An individual style and "quality of life" are linked to daily life. However, socio-political dimensions have an impact on it. This is due to the conviction that "stratification and organization are deeply rooted in interactions of daily life", ${ }^{8}$ and opportunities and careers directly depend on them (Sztompka, 2008, pp. 30-33).

8 R. Collins, Conflict Theory and the Advance of Macro-Historical Sociology. In: G. Ritzer (Ed.), Frontiers of Social Theory. The New Syntheses. New York 1990, p. 70 (quoted in: Szacki, 2003, p. 835). 
Turbulences experienced in the socio-political world in the process of integration with the EU, sometimes really dramatic and different in all the Visegrad Group countries, apply to the environments with indigenous minority. The character of the issues concerning minorities involves the issue of belonging to various groups of reference or their schools. It relates to the issue of providing equal opportunities and access to resources, including future education and career opportunities: "The notion of social justice has always been controversial. To what extent does it entail redistribution of wealth and revenues and to what extent improving of equality of access to opportunities?” (Giddens, 2009, p. 92).

Translated by Jadwiga Suchoń

\section{References}

Domański, H. (2002). Mechanizmy stratyfikacji i hierarchie społeczne. In: M. Marody (Ed.), Wymiary życia społecznego. Polska na przełomie XX i XXI wieku (pp. 67-92). Warszawa: Scholar.

Domański, H. (2004). Struktura społeczna. Warszawa: Wydawnictwo Naukowe Scholar.

Dyoniziak, R., Iwanicka, K., Karwińska, A., Nikołajew, J., \& Pucek, Z. (1999). Społeczeństwo w procesie zmian. Zarys socjologii ogólnej. Edition 3 extended and amended. Zielona Góra: Zachodnie Centrum Organizacji.

Giddens, A. (2009). Europa w epoce globalnej. Warszawa: Wydawnictwo Naukowe PWN.

Grzybowski, P.P. (2007). Edukacja europejska - od wielokulturowości ku międzykulturowości. Koncepcje edukacji wielokulturowej i międzykulturowej w kontekście europejskim ze szczególnym uwzględnieniem środowiska frankofońskiego. Kraków: Oficyna Wydawnicza „Impuls”.

Jasińska-Kania, A., \& Łodziński, S. (2009). Wprowadzenie. In: A. Jasińska-Kania, \& S. Łodziński (Eds.), Obszary i formy wykluczania etnicznego w Polsce. Mniejszości narodowe, imigranci, uchodźcy (pp. 7-38). Warszawa: Wydawnictwo Naukowe Scholar.

Kempny, M. (1997). Wielokulturowość ‘ante portas’! O wielości kultur, języków i różnych kontekstach. Kilka uwag na zakończenie. In: M. Kempny, A. Kapciak, \& S. Łodziński (Eds.), U progu wielokulturowości. Nowe oblicza społeczeństwa polskiego (pp. 272-294). Warszawa: Oficyna Naukowa.

Kubiak, H. (1980). Teoria, ideologia, polityka asymilacji. Szkic problemu. In: H. Kubiak, \& A.K. Paluch (Eds.), Założenia teorii asymilacji. Polska Akademia Nauk, Komitet Badania Polonii (pp. 15-25). Wrocław: Zakład Narodowy im. Ossolińskich.

Lewowicki, T. (2011). Cztery spojrzenia na wielokulturowość i edukację międzykulturową. In: J. Nikitorowicz, A. Sadowski, \& D. Misiejuk (Eds.), Edukacja międzykulturowa. Part 1. Pogranicze. Studia Społeczne. Vol. XVII (pp. 28-37). Białystok: Wydawnictwo Uniwersytetu w Białymstoku.

Machaj, I. (2004). Wprowadzenie do socjologicznych zagadnień mikrostruktur społecznych. In: I. Machaj (compilation and preface), Małe struktury społeczne (pp. 9-39). Lublin: Wydawnictwo Uniwersytetu Marii Curie-Skłodowskiej.

Merton, R.K. (1982). Teoria socjologiczna i struktura społeczna. Warszawa: PWN. 
Miluska, J. (1995). Relacyjny model rozwoju tożsamości grupowej. In: M.M. Urlińska (Ed.), Edukacja a tożsamość etniczna. Materiały z konferencji naukowej w Rabce (pp. 37-50). Toruń: Wydawnictwo Uniwersytetu Mikołaja Kopernika.

Olbrycht, K. (2003). Rola kształcenia aksjologicznego w działaniach pedagogicznych w społecznościach wielokulturowych. In: T. Lewowicki, E. Ogrodzka-Mazur, \& A. Gajdzica, (Eds.), Świat wartości i edukacja międzykulturowa (pp. 212-219). Cieszyn-Warszawa: Uniwersytet Śląski Filia w Cieszynie, Wyższa Szkoła Pedagogiczna ZNP w Warszawie. Paleczny, T. (2009). Przedmowa. In: T. Paleczny, \& M. Banaś (Eds.), Dialog na pograniczach kultur i cywilizacji (pp. 11-21). Kraków: Wydawnictwo Uniwersytetu Jagiellońskiego.

Posern-Zielińska, M. (1975). Źródła relatywnej deprywacji a geneza ‘shakeryzmu’. Etnografia Polska, 19(2), pp. 149-181.

Sierocińska, K. (2011). Kapitał społeczny. Definiowanie, pomiar i typy. Studia Ekonomiczne, 1, pp. 69-86.

Skeris, P. (1979). Teoria grup odniesienia. Studium mechanizmów interakcji międzyludzkich. Lublin: Redakcja Wydawnictw Katolickiego Uniwersytetu Lubelskiego.

Skeris, P. (2004). Pojęcie „grupy odniesienia”. In: I. Machaj (compilation and preface), Małe struktury społeczne (pp. 115-119). Lublin: Wydawnictwo Uniwersytetu Marii Curie-Skłodowskiej.

Sowa, J. (1962). Teoria grup odniesienia. Studia Socjologiczne, 4, pp. 41-73.

Szacki, J. (2003). Historia myśli socjologicznej. Warszawa: Wydawnictwo Naukowe PWN.

Szmatka, P.J. (2008). Małe struktury społeczne. Wstęp do mikrosocjologii strukturalnej. $2^{\text {nd }}$ ed. 1 reprint. Warszawa: PWN.

Sztompka, P. (1989). Pojęcie struktury społecznej. Próba uogólnienia. Studia Socjologiczne, 3, pp. 56-65.

Sztompka, P. (2008). Życie codzienne - temat najnowszej socjologii. In: P. Sztompka, \& M. Bogunia-Borowska (Eds.), Socjologia codzienności (pp. 15-52). Kraków: Wydawnictwo Znak.

Taylor, Ch. (1995). Źródła współczesnej tożsamości. Transl. S. Amsterdamski. In: K. Michalski (Ed.), Tożsamość w czasie zmiany. Rozmowy w Castel Gandolfo (pp. 11-26). Kraków: Znak.

Urban, J. (2014). Mniejszości narodowe krajów Grupy Wyszehradzkiej w procesach integracyjnych Europy - tożsamość młodzieży mniejszości autochtonicznych. Toruń: Wydawnictwo Adam Marszałek.

Witkowski, L. (1995). Ambiwalencja tożsamości z pogranicza kulturowego. In: M.M. Urlińska (Ed.), Edukacja a tożsamość etniczna. Materiały z konferencji naukowej w Rabce (pp. 11-23). Toruń: Wydawnictwo Uniwersytetu Mikołaja Kopernika.

\section{Online Sources}

Rex, J. (1996). National Identity in the Democratic Multi-Cultural State. Sociological Research Online, 1(2). Retrieved from: http://www.socresonline.org.uk/1/2/1.html (accessed: August 21, 2013). 